\title{
Preparation of the ferrocene-substituted 1,3-distal p-tert-butylcalix[4] arene based QCM sensors array and utilization of its gas-sensing affinities
}

\author{
Serkan Sayin ${ }^{\text {a, * }}$, Cebrail Ozbek ${ }^{\text {b }}$, Salih Okur ${ }^{\text {b, c }}$, Mustafa Yilmaz ${ }^{\text {a }}$ \\ a Selcuk University, Department of Chemistry, Konya, Turkey \\ ${ }^{\mathrm{b}}$ Izmir Institute of Technology, Faculty of Science, Department of Physics, Urla, Izmir, Turkey

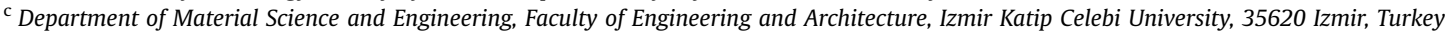

\section{A R T I C L E I N F O}

\section{Article history:}

Received 19 March 2014

Received in revised form

3 June 2014

Accepted 4 June 2014

Available online 12 June 2014

Keywords:

Calixarene

Ferrocene

QCM electrode

Carbon dioxide sensing

Carbon monoxide sensing

\begin{abstract}
A B S T R A C T
The article describes the synthesis of the new ferrocene-substituted calix[4]arene derivative 4 as sensitive layer, and suggests that the immobilization of it is on a quartz crystal microbalance gold electrode via the drop-casting method in order to produce the calix[4]arene-based QCM sensor. In addition, sensor response of the calix[4]arene-based QCM sensor was investigated towards carbon dioxide $\left(\mathrm{CO}_{2}\right)$ and carbon monoxide (CO). The sensing and selectivity studies show that the ferrocene-substituted calix[4] arene-based QCM sensor is an effective gas sensor toward both carbon dioxide and carbon monoxide.
\end{abstract}

(C) 2014 Elsevier B.V. All rights reserved.

\section{Introduction}

Carbon dioxide and carbon monoxide are known serious hazard gases for living systems in the atmosphere [1-8]. An increasing concentration of carbon dioxide along with the other greenhouse gases in the atmosphere, is causing the global temperature to increase, and results in its toxic and harmful effects which reaches both people and fauna alike [1-3]. Carbon dioxide is released into the environment by anthropologic movements, fossil fuel combustion, cement production, sewers, grain silos, ship holds, spacecrafts, and submarines [4,5]. Carbon monoxide is also known to be toxic and dangerous for living systems in multiple environments. A dangerous effect is seen in humans, especially, as the bloodstream carries carbon monoxide through the lungs, and causes carbon monoxide to interact with hemoglobin $(\mathrm{Hb})$, which carries the body's oxygen. This interaction creates carboxyhemoglobin ( $\mathrm{COHb}$ ), thereby reducing the oxygen-delivering capacity of the blood leading to the organs and tissues [7,8]. In high concentrations, carbon monoxide causes fatal intoxication in humans [9].

\footnotetext{
* Corresponding author. Fax: +90 3322410106

E-mail address: saynserkan@gmail.com (S. Sayin).
}

Calixarenes, produced by a condensation reaction of phenol and formaldehyde represent very useful building blocks in supramolecular chemistry [10-13]. Indeed, their easy preparation, unlimited functionalization, and differently-sized cavities of calixarenes make them unique macrocyclic compounds [14-16]. These advantages help calixarenes acquire the promising organic materials for enzyme-mimics, ion carriers, solid-phase support materials, ion selective electrodes, drug-delivery agents, and catalysis applications [17-20]. Chemical modification of them with various functional groups also provides selectivity associating with their complexation properties depending on host-guest, electrostatic, hydrogen bonding, ion-dipole, and dipole-dipole interactions [19-23]. Regarding these properties, calixarenes have also been employed as gas sensors for $\mathrm{NO}_{2}, \mathrm{CO}_{2}$, and $\mathrm{CO}$, as well as humidity gases [24-26].

In the present study, an amino derivative of calixarene was reacted with ferrocene carboxaldehyde, which exhibits anion recognition effects based on a strong electrostatic interaction, to produce a new ferrocene-conjugated calixarene derivative as an effective sensor for toxic gases. The ferrocene-conjugated calixarene derivative was immobilized for the first time onto a quartz crystal microbalence gold electrode via the drop-casting method in order to investigate its sensor capacity towards carbon monoxide and carbon dioxide gases by using quartz crystal microbalence 
(QCM) techniques, the preferred technique for determining the sorption properties of hosts with respect to the specific gas as a guest.

\section{Experimental}

\section{General remarks}

TLC analyses were carried out on DC Alufolien Kieselgel $60 \mathrm{~F}_{254}$ (Merck). All reactions, unless otherwise noted, were conducted under a nitrogen atmosphere. All starting materials and reagents used were of standard analytical grade from Merck or Aldrich and used without further purification. ${ }^{1} \mathrm{H}$ NMR was recorded on a Varian $400 \mathrm{MHz}$ spectrometer. FTIR spectra were obtained on a Perkin-Elmer 1605 FTIR spectrometer using $\mathrm{KBr}$ pellets and 100/ ATR Sampling Accessory. The cyclic voltammetric (CV) studies were carried out according to the literature procedure [27]. Elemental analyses were performed using a Leco CHNS-932 analyzer. Melting points were determined on a Gallenkamp apparatus in a sealed capillary glass tube and are uncorrected. A Shimadzu 160 A UV-vis apparatus was used to analyze absorbance of the ferroceneconjugated p-tert-butylcalix[4]arene (4) in $\mathrm{CH}_{2} \mathrm{Cl}_{2}$ solutions.

\section{Syntheses}

The syntheses of compounds $\mathbf{1} \mathbf{- 3}$ were carried out according to the literature procedures [28-30]. The ferrocene-substituted calix [4]arene (4) is herein reported for the first time.

Synthesis of p-tert-butylcalix[4]arene-diester (2)

Yield: $14 \mathrm{~g}$ (63.4\%); mp: $202-207^{\circ} \mathrm{C}$. FTIR (KBr): $1750 \mathrm{~cm}^{-1}(\mathrm{C}=$ O). ${ }^{1} \mathrm{H}$ NMR $\left(\mathrm{CDCl}_{3}\right): \delta 0.97\left(\mathrm{~s}, 18 \mathrm{H}, \mathrm{Bu}^{\mathrm{t}}\right), 1.24\left(\mathrm{~s}, 18 \mathrm{H}, \mathrm{Bu}^{\mathrm{t}}\right), 3.35(\mathrm{~d}$, $\left.4 \mathrm{H}, J=12.6 \mathrm{~Hz}, \mathrm{Ar}-\mathrm{CH}_{2}-\mathrm{Ar}\right), 3.85\left(\mathrm{~s}, 6 \mathrm{H},-\mathrm{OCH}_{3}\right), 4.45(\mathrm{~d}, 4 \mathrm{H}$, $\left.J=12.6, \mathrm{Ar}-\mathrm{CH}_{2}-\mathrm{Ar}\right), 4.78\left(\mathrm{~s}, 4 \mathrm{H},-\mathrm{OCH}_{2} \mathrm{CO}\right), 6.85$ (s, 4H, $\left.\mathrm{ArH}\right), 7.05$ (s, 4H, ArH), 7.10 (s, 2H, OH).

Synthesis of 5,11,17,23-tetra-tert-butyl-25,27dihydrazinamidecarbonylmethoxy-26,28-dihydroxy-calix[4]arene (3)

Yield: $1.6 \mathrm{~g}$ (53.3\%); mp: $330-333{ }^{\circ} \mathrm{C}$. FTIR (KBr): $1687 \mathrm{~cm}^{-1}$ $(\mathrm{N}-\mathrm{C}=\mathrm{O}) .{ }^{1} \mathrm{H}$ NMR $\left(400 \mathrm{MHz}, \mathrm{CDCl}_{3}\right): \delta 1.02\left(\mathrm{~s}, 18 \mathrm{H}, \mathrm{Bu}^{\mathrm{t}}\right), 1.26(\mathrm{~s}$, $\left.18 \mathrm{H}, \mathrm{Bu}^{\mathrm{t}}\right), 2.15\left(\mathrm{~d}, 4 \mathrm{H}, J=1.6 \mathrm{~Hz}, \mathrm{NH}_{2}\right), 3.42(\mathrm{~d}, 4 \mathrm{H}, J=13.3 \mathrm{~Hz}$, $\left.\mathrm{Ar}-\mathrm{CH}_{2}-\mathrm{Ar}\right), 4.11\left(\mathrm{~d}, 4 \mathrm{H}, J=13.2 \mathrm{~Hz}, \mathrm{Ar}-\mathrm{CH}_{2}-\mathrm{Ar}\right), 4.63(\mathrm{~s}, 4 \mathrm{H}$, $-\mathrm{OCH}_{2}$ ), 6.92 (s, 4H, $\left.\mathrm{ArH}\right), 7.10$ (s, 4H, $\left.\operatorname{ArH}\right), 7.70$ (s, 2H, $\left.-\mathrm{OH}\right), 9.61$ (brs, $2 \mathrm{H}, \mathrm{NH}$ ).

Synthesis of ferrocene-conjugated p-tert-butylcalix[4]arene (4)

To a solution of $\mathbf{3}(0.6 \mathrm{~g}, 0.756 \mathrm{mmol})$ in $30 \mathrm{~mL} \mathrm{THF}$, a solution of ferrocene carboxyaldehyde $(0.3 \mathrm{~g}, 1.542 \mathrm{mmol})$ in $150 \mathrm{~mL}$ THF was added. The reaction mixture was refluxed for 2 days. The volatile component was evaporated to dryness, and the residue was dissolved in $\mathrm{CHCl}_{3}$ and washed with water to adjust $\mathrm{pH}$ 7.0. The organic layer was then dried over $\mathrm{MgSO}_{4}$, filtered off and evaporated to dryness. The crude was purified by column chromatography $\left(\mathrm{SiO}_{2}\right.$, EtOAc/MeOH, 20/1). Yield: 85\%, m.p.; $184-186{ }^{\circ} \mathrm{C}$. FTIR (ATR) $\mathrm{cm}^{-1}: 1641(\mathrm{CH}=\mathrm{N})$ and $1674(\mathrm{C}=\mathrm{O}) .{ }^{1} \mathrm{H}$ NMR $(400 \mathrm{MHz}$, $\left.\mathrm{CDCl}_{3}\right): \delta 8.20(\mathrm{~s}, 2 \mathrm{H}, \mathrm{HC}=\mathrm{N}), 7.52(\mathrm{~s}, 2 \mathrm{H},-\mathrm{NH}), 7.13(\mathrm{~s}, 4 \mathrm{H}, \mathrm{ArH})$, $7.09(\mathrm{~s}, 2 \mathrm{H},-\mathrm{OH}), 6.91(\mathrm{~s}, 4 \mathrm{H}, \mathrm{ArH}), 4.75\left(\mathrm{~s}, 4 \mathrm{H}, \mathrm{OCH}_{2}\right), 4.66$ (brs, $4 \mathrm{H}$, $\left.\mathrm{C}_{5} \mathrm{H}_{4}\right), 4.37$ (brs, $\left.4 \mathrm{H}, \mathrm{C}_{5} \mathrm{H}_{4}\right), 4.14-4.21\left(\mathrm{~m}, 14 \mathrm{H}, \mathrm{Ar}-\mathrm{CH}_{2}-\mathrm{Ar}\right.$ and $\left.\mathrm{C}_{5} \mathrm{H}_{5}\right), 3.51$ (d, $\left.4 \mathrm{H}, J=13.5 \mathrm{~Hz}, \mathrm{Ar}-\mathrm{CH}_{2}-\mathrm{Ar}\right), 1.27$ (brs, $\left.18 \mathrm{H}, \mathrm{Bu}^{\mathrm{t}}\right), 1.0$ (brs, 18H, Bu ${ }^{\mathrm{t}}$ ). ${ }^{13} \mathrm{C}$ NMR (100 MHz, CDCl 3 ): $\delta 169.26$ (CO), 153.60, 153.03, 150.43, 139.53, 139,48, 129.46, 129.21, 126.02, 125.25, 76.21, 73.94, 73.80, 68.57, 67.92, 38.98, 37.24, 31.54. Anal. Calcd. for $\mathrm{C}_{70} \mathrm{H}_{80} \mathrm{Fe}_{2} \mathrm{~N}_{4} \mathrm{O}_{6}: \mathrm{C}, 70.94 ; \mathrm{H}, 6.80 ; \mathrm{N}, 4.73$. Found (\%): C, 70.74; $\mathrm{H}$, $6.91 ; \mathrm{N}, 4.68$.

\section{Preparation of QCM electrodes}

In order to prepare QCM electrodes, $4.7 \mathrm{mg}$ of the ferrocenesubstituted calixarene $\mathbf{4}$ or $2.6 \mathrm{mg}$ of p-tert-butylcalix[4]arene $\mathbf{1}$, which was used as a reference molecule, was dissolved in $4 \mathrm{~mL}$ of chloroform, respectively. The prepared solutions, each of which were $1 \mathrm{mM}$, were ultrasonicated for an hour to dissolve the compound thoroughly. Finally, the prepared solutions were kept at room temperature for $48 \mathrm{~h}$. The step after preparation of the solutions was to clean the surface of gold coated QCM electrodes as follows: the QCM electrodes were cleaned in an ultrasonic bath in acetone, ethanol, propanol and distilled water for $15 \mathrm{~min}$, respectively and then dried with high purity nitrogen. After cleaning QCM electrodes, $5 \mu \mathrm{L}$ of each solution was dropped onto them and they were kept at room temperature to dry. The structures of the calixarene-modified QCM electrodes were determined by FTIR spectrum (see Fig. 1).

Adsorption and desorption of the ferrocene-substituted calix[4] arene $\mathbf{4}$ and $p$-tert-butylcalix[4]arene $\mathbf{1}$ were investigated under exposure of $\mathrm{CO}$ and $\mathrm{CO}_{2}$ gas. Gas sensing properties of each derivative was investigated by using the Quartz Crystal Microbalance (QCM) technique. A 2-channel gas-flow system controlled via PC was set. Gas sensor responses of each calixarene film were measured by the frequency shift response with a flow gas system according to the Sauerbrey relation. The schematic of the measurement system is depicted in Fig. 2. A time-resolved electrochemical QCM (EQCM) with the model of CHI400A Series from $\mathrm{CH}$ Instruments (Austin, USA) was used to measure the change in the resonance frequency of quartz crystals between gold electrodes during adsorption and desorption. The range of oscillation frequencies of QCM is between 7.995 $\mathrm{MHz}$ and $7.950 \mathrm{MHz}$. AT- cut quartz crystals with a fundamental frequency of $7.995 \mathrm{MHz}$ were obtained from International Crystal Manufacturing Co. (ICM). The density $(\rho)$ of the crystal is $2.684 \mathrm{~g} / \mathrm{cm}^{3}$, and the shear modulus $(\mu)$ of quartz is $2.947 \times 1011 \mathrm{~g} / \mathrm{cm} \mathrm{s}^{2}$. Around oscillation frequency of $7.995 \mathrm{MHz}$, a net change of $1 \mathrm{~Hz}$ corresponds to $1.34 \mathrm{ng}$ of gas molecules adsorbed or desorbed onto the crystal surface of an area of $0.196 \mathrm{~cm}^{2}$. Gas flow into test cell were supplied by two mass flow meters (MKS,179A Mass-Flo ${ }^{\circledR}$ ) and RS232 controlled gas flow control unit (MKS).

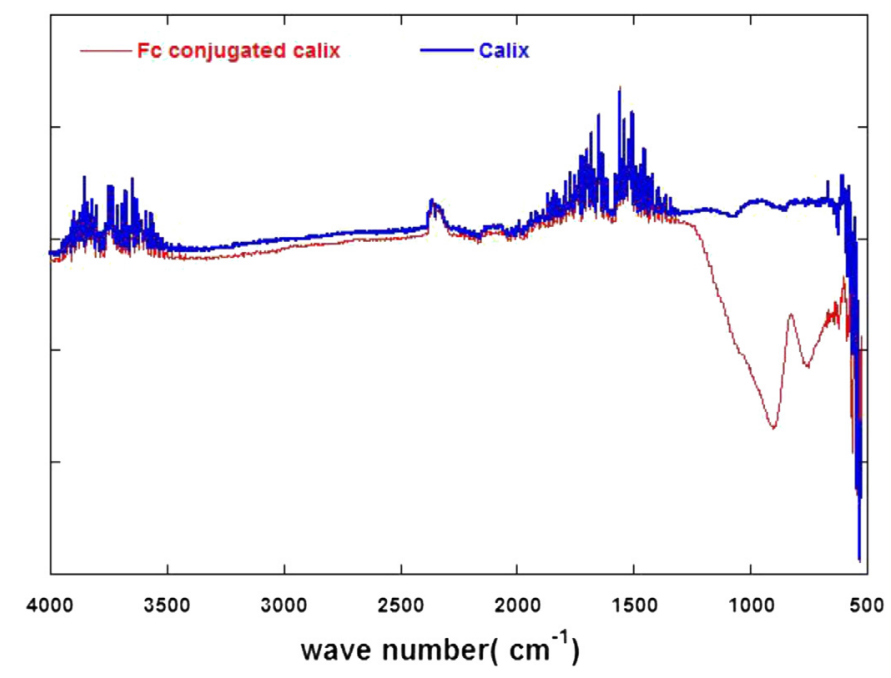

Fig. 1. FTIR spectra of the calixarene-modified QCM electrodes. 


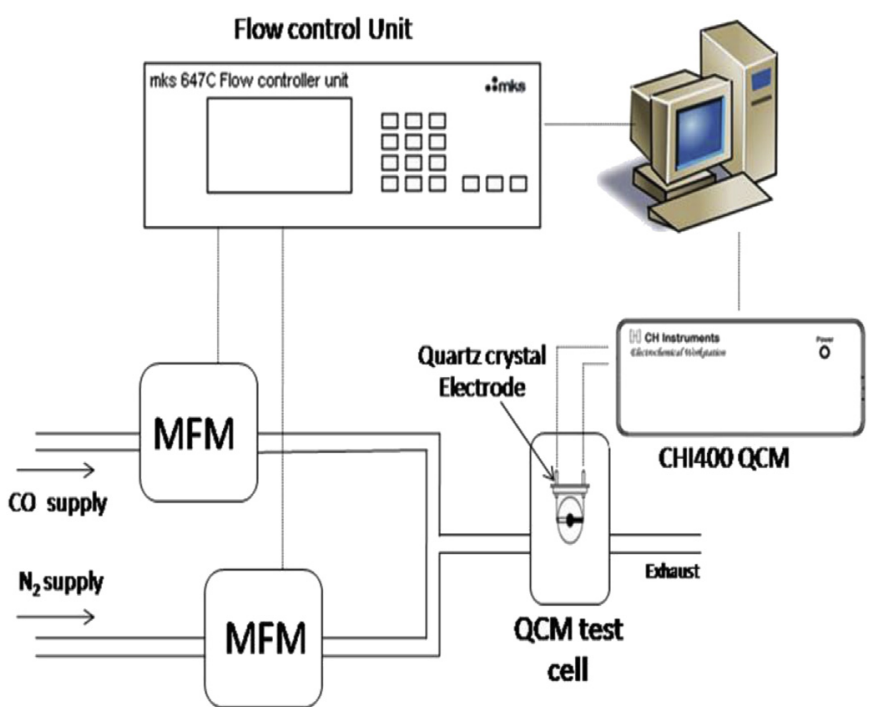

Fig. 2. An experimental QCM setup of calixarene derivatives under different gases.

\section{Results and discussion}

Selectively synthesis of calixarene containing organoiron derivative as a sensor

The main goal of this work was the synthesis of a new calixarene, containing organoiron derivative $\mathbf{4}$, and the exploration of its binding properties toward carbon monoxide and carbon dioxide gases as a new effective sensor. For this purpose, $p$-tert-butylcalix[4] arene $\mathbf{1}$, and its diester derivative $\mathbf{2}$, were synthesized according to the literature procedures $[28,29]$. The functionalization of the diester derivative $\mathbf{2}$ at the lower rim was conducted with hydrazine to produce 5,11,17,23-tetra-tert-butyl-25,27-dihydrazinamidecar bonylmethoxy-26,28-dihydroxy-calix[4]arene (3) according to the literature [30]. Next, 3 was treated with ferrocene carboxaldehyde to produce a target calixarene-organoiron derivative $\mathbf{4}$ (Scheme 1). All calixarene derivatives were characterized by using FTIR, ${ }^{1} \mathrm{H}$ NMR and elemental analysis techniques.

The FTIR spectra of the ferrocene-substituted calixarene 4 confirms its structure by appearing additional peak at $1641 \mathrm{~cm}^{-1}$ wherein belongs the vibration stretch of $\mathrm{CH}=\mathrm{N}$ bond. Moreover, ${ }^{1} \mathrm{H}$ NMR spectrum also confirms the formation of the ferrocenesubstituted calixarene 4 by the appearance of the characteristic peak of imine protons $(\mathrm{HC}=\mathrm{N})$ at $8.20 \mathrm{ppm}$.

The UV-vis spectra for 4 in $\mathrm{CH}_{2} \mathrm{Cl}_{2}$ solvent at $200-600 \mathrm{~nm}$ are depicted in Fig. 3. The ferrocene-substituted calixarene $\mathbf{4}$ exhibits a strong absorption at $290 \mathrm{~nm}$, corresponding to the $\pi \rightarrow \pi^{*}$ transitions, and a weak band at $460 \mathrm{~nm}$ due to the $\mathrm{d}-\mathrm{d}$ transition for the iron of ferrocene [27].

The cyclic voltammetric (CV) study was used to investigate the electrochemical properties of the ferrocene-substituted calixarene 4 (see Fig. 4). From the CV, it is clearly seen that the ferrocenesubstituted calixarene $\mathbf{4}$ exhibit one reversible oxidation wave $\mathrm{Fc}-\mathrm{Fc}^{+}$at $\mathrm{E}_{1 / 2}=0.53 \mathrm{~V}$. The oxidation states given in Fig. indicate that calixarene has an electronic communication with the ferrocene units.

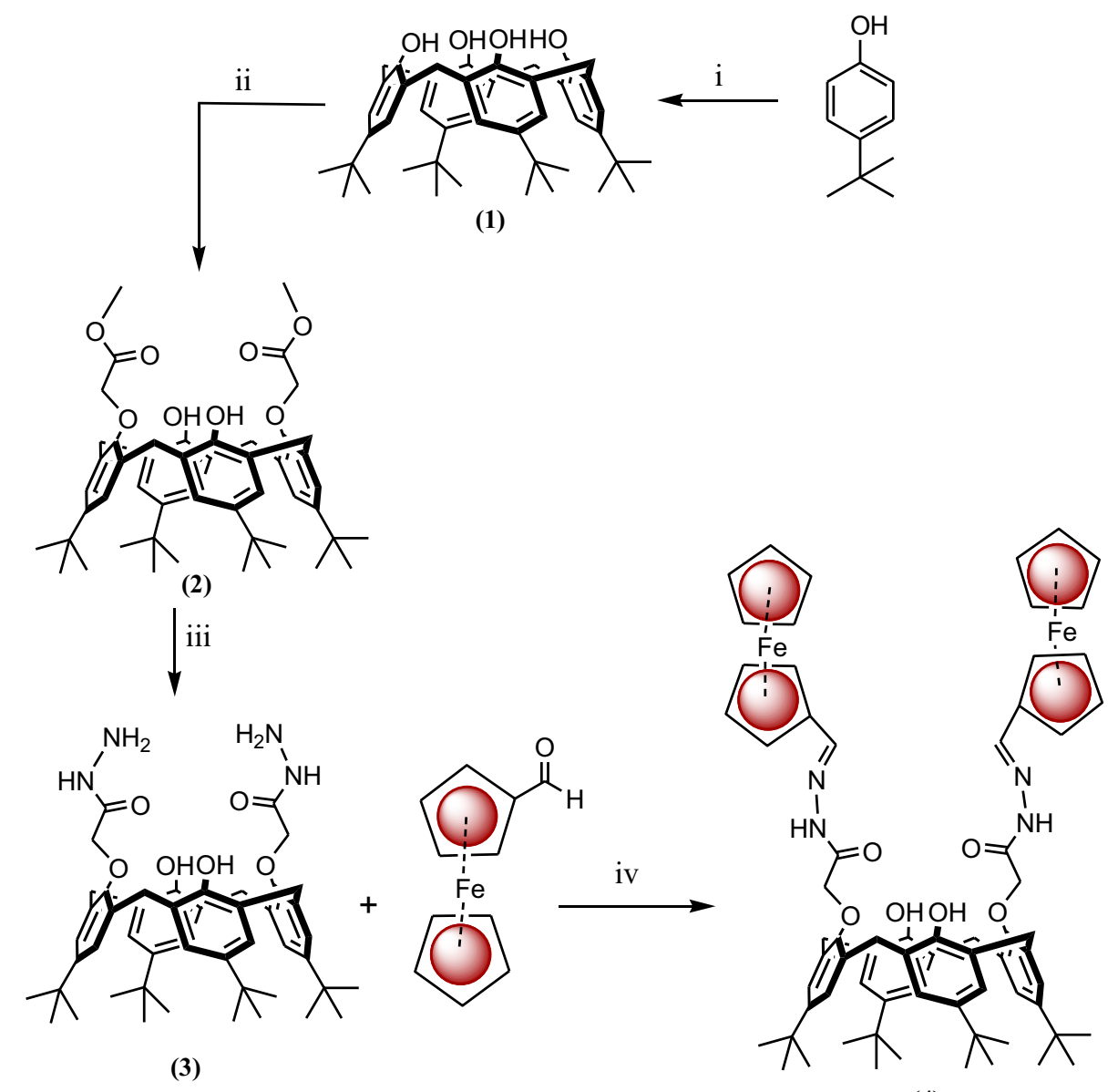

(4)

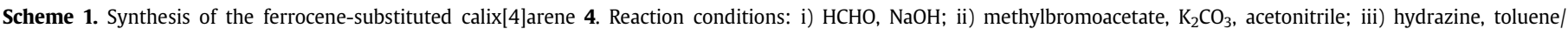
methanol; iv) THF. 


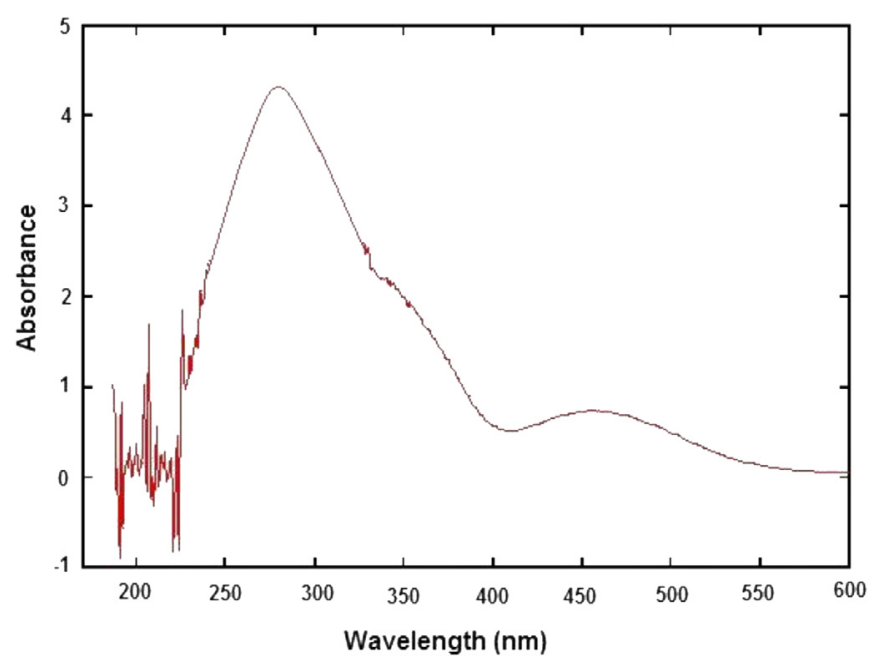

Fig. 3. UV-vis spectrum of the ferrocene-substituted calix[4] arene $\mathbf{4}\left(1.0 \times 10^{-5} \mathrm{M}\right.$ in $\mathrm{CH}_{2} \mathrm{Cl}_{2}$ ).

\section{Sensing studies}

The removal of carbon monoxide ( $\mathrm{CO}$ ) and carbon dioxide gases $\left(\mathrm{CO}_{2}\right)$ from the atmosphere has gained high levels of attention because of the toxic and serious hazardous effects of the gases on the living systems. For this purpose, we were interested in synthesizing a new p-tert-butylcalix[4]arene derivative at lower rim, substituted with the ferrocene units as a host having well-binding lobes for carbon monoxide and carbon dioxide gases. In order to estimate sensing capacity of the ferrocene-substituted calixarene $\mathbf{4}$, it was immobilized onto a quartz crystal microbalence gold electrode via the drop-casting method [26]. Additionally, to determine the impact of the organoiron units (ferrocene) of product $\mathbf{4}$ in the sensing studies, $p$-tert-butylcalix[4]arene $\mathbf{1}$ was also immobilized onto a quartz crystal microbalence gold electrode.

The sensing results indicated that the frequency responses of $p$ tert-butylcalix[4]arene $\mathbf{1}$ immobilized QCM and the ferrocenesubstituted calixarene $\mathbf{4}$ immobilized QCM electrodes during the sorption process under $\mathrm{CO}$ and $\mathrm{CO}_{2}$ gases (Figs. 5 and 6). Figs. 5 and 6 show that all calixarene-immobilized QCM electrodes have different responses towards carbon monoxide and carbon dioxide. The reason why the $\mathrm{QCM}$ electrode-immobilized with p-tert-

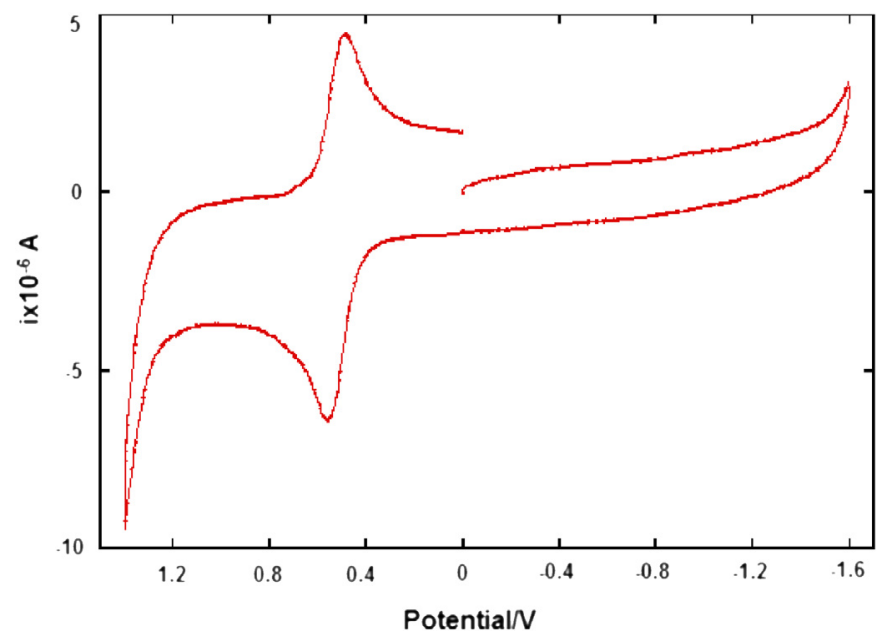

Fig. 4. Cyclic voltammogram of the ferrocene-substituted calix[4]arene $4\left(1.0 \times 10^{-4} \mathrm{M}\right.$ solution in $\mathrm{CH}_{2} \mathrm{Cl}_{2}$, and $0.1 \mathrm{M} \mathrm{Bu}_{4} \mathrm{NPF}_{6}$ ) estimated at a scan speed of $100 \mathrm{mV} / \mathrm{s}$.

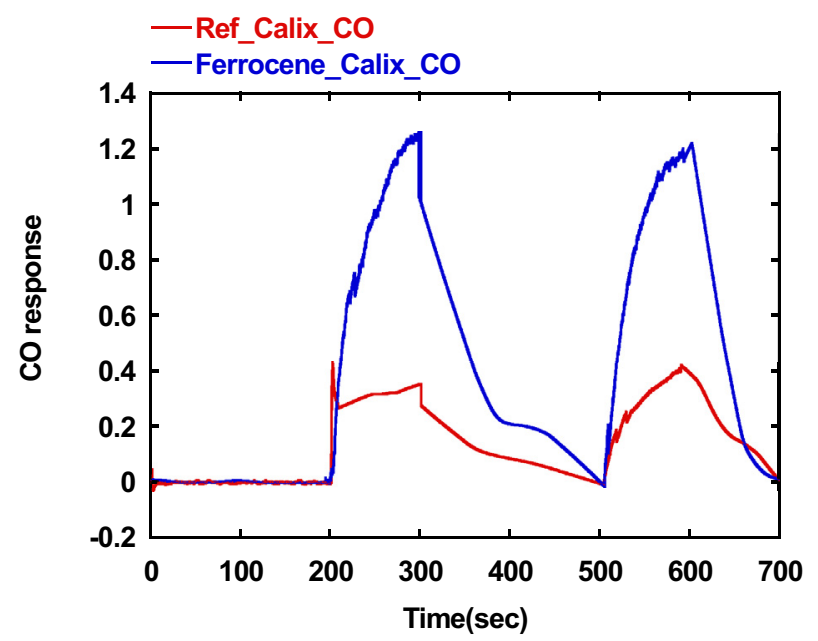

Fig. 5. QCM frequency shifts of the QCM electrode modified with ferrocenesubstituted calix[4]arene $\mathbf{4}$ (Ferrocene_Calix_CO) and the QCM electrode coated with p-tert-butylcalix[4]arene 1 (Ref_Calix_CO) for adsorption and desorption cycles under carbon monoxide gase (CO).

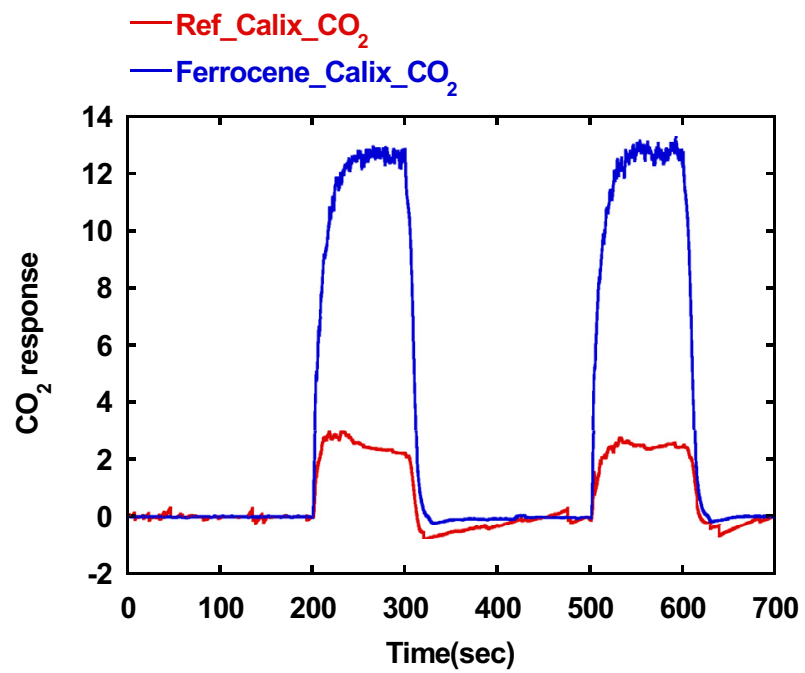

Fig. 6. QCM frequency shifts of the QCM electrode coated with ferrocene-substituted calix[4]arene 4 (Ferrocene_Calix_CO2) and the QCM electrode coated with p-tertbutylcalix[4]arene 1 (Ref_Calix_CO2) for adsorption and desorption cycles under carbon dioxide gase $\left(\mathrm{CO}_{2}\right)$.

butylcalix[4]arene 1 has a sensing capacity for $\mathrm{CO}$ and $\mathrm{CO}_{2}$ gases might be that calixarenes have a rigid structure and also have strong complexation abilities such as host-guest, ion-dipole, dipole-dipole, and hydrogen bonding interactions. However, the fact that the QCM electrode-immobilized with the ferrocenesubstituted calixarene $\mathbf{4}$ exhibited more sensing affinity than the QCM electrode-immobilized with $p$-tert-butylcalix[4]arene $\mathbf{1}$ for both gases would be assessed. This result was not surprising, because the organoiron units (ferrocene) of calixarene 4 provide additional complexation properties, such as cooperative affinities and strong anion binding capabilities, to calixarene derivatives.

\section{Conclusion}

A new the ferrocene-substituted calix[4]arene $\mathbf{4}$ was synthesized and then immobilized onto the surface of a quartz crystal microbalence gold electrode by using the drop-casting method to fabricate an organoiron-substituted calixarene-based QCM 
electrode for the sensing of carbon monoxide and carbon dioxide gases. p-tert-Butylcalix[4]arene was also immobilized onto the QCM electrode, and its sensing capacity toward $\mathrm{CO}$ and $\mathrm{CO}_{2}$ gases was investigated in order to compare and estimate the importance of the calixarene contained within the ferrocene units. The results indicated that both calixarene-immobilized QCM electrodes depend on strong complexation properties of the calixarene framework, such as host-guest, ion-dipole, dipole-dipole, and hydrogen bonding interactions, which were effective receptors for the adsorption of $\mathrm{CO}$ and $\mathrm{CO}_{2}$ gases. However, the $\mathrm{QCM}$ electrode coated with ferrocene-substituted calix[4]arene $\mathbf{4}$ exhibited higher sensing affinity than the QCM electrode coated with $p$-tert-butylcalix[4]arene because it acquired more complexation properties, such as strongly anion binding and cooperative abilities, which came with the organoiron units of calixarene derivative. Hence, offering more complexation abilities of the QCM electrode coated with ferrocene-substituted calix[4]arene 4 would open new options for gas-sensing applications.

\section{Acknowledgments}

This research was supported by Tubitak (Turkish Scientific Association) under project number TBAG 109T240.

\section{References}

[1] P.E. Dennison, A.K. Thorpe, E.R. Pardyjak, D.A. Roberts, Y. Qi, R.O. Green, E.S. Bradley, C.C. Funk, Remote Sens. Environ. 139 (2013) 116.

[2] P. Forster, V. Ramaswamy, P. Artaxo, T. Berntsen, R. Betts, D.W. Fahey, J. Haywood, J. Lean, D.C. Lowe, G. Myhre, J. Nganga, R. Prinn, G. Raga, M. Schulz, R.V. Dorland, et al., Changes in atmospheric constituents and in radiative forcing, in: S. Solomon, D. Qin, M. Manning, Z. Chen, M. Marquis, K.B. Averyt, M. Tignor, H.L. Miller (Eds.), Climate Change 2007: The Physical Science Basis: Contribution of Working Group I to the Fourth Assessment Report of the Intergovernmental Panel on Climate Change, Cambridge University Press, Cambridge, 2007, pp. 129-234.
[3] Q. Xu, S. Lee, Y. Cho, M.H. Kim, J. Bouffard, J. Yoon, J. Am. Chem. Soc. 135 (2013) 17751.

[4] T.A. Boden, G. Marland, R.J. Andres, Global, Regional, and National Fossil-fuel $\mathrm{CO}_{2}$ Emissions, Carbon Dioxide Information Analysis Center, Oak Ridge National Laboratory, U.S. Department of Energy, Oak Ridge, Tenn., USA, 2011.

[5] NOAA, GMD Measurement locations: NationalOceanic\&Atmospheric Administration (NOAA), Earth System Research Laboratory, Global Monitoring Division, 2012. http://www.esrl.noaa.gov/gmd/ccgg/trends/global.html.

[6] S.H. Brunssen, D.L. Morgan, F.M. Parham, G.J. Harry, Toxicology 194 (2003) 51.

[7] J.A. Raub, V.A. Benignus, Neurosci. Biobehav. Rev. 26 (2002) 925.

[8] D.J. Suh, C. Kwak, J.-H. Kim, S.M. Kwon, T.-J. Park, J. Power Sources 142 (2005) 70.

[9] F.A. Jaffe, Am. J. Forensic Med. Pathol. 18 (1997) 406.

[10] P. Slavik, M. Dudic, K. Flidrova, J. Sykora, I. Cisarova, S. Böhm, P. Lhoták, Org. Lett. 14 (2012) 3628.

[11] A. Casnati, Chem. Commun. 49 (2013) 6827.

[12] Y.H. Lee, H. Liu, J.Y. Lee, S.H. Kim, S.K. Kim, J.L. Sessler, Y. Kim, J.S. Kim, Chem. Eur. J. 16 (2010) 5895.

[13] F.N. Memon, S. Memon, N. Memon, J. Chem. Eng. Data 56 (2011) 3336.

[14] F. Cardona, G. Isoldi, F. Sansone, A. Casnati, A. Goti, J. Org. Chem. 77 (2012) 6980.

[15] S. Sayin, G.U. Akkuș, R. Cibulka, I. Stibor, M. Yilmaz, Helv. Chim. Acta 94 (2011)

[16] R. Sun, C. Xue, X. Ma, M. Gao, H. Tian, Q. Li, J. Am. Chem. Soc. 135 (2013) 5990.

[17] S. Sayin, E. Yilmaz, M. Yilmaz, Org. Biomol. Chem. 9 (2011) 4021.

[18] Ö.Ö. Karakuș, H. Deligöz, Anal. Lett. 43 (2010) 768.

[19] L. Baldini, R. Cacciapaglia, A. Casnati, L. Mandolini, R. Salvio, F. Sansone, R. Ungaro, J. Org. Chem. 77 (2012) 3381.

[20] S. Sayin, M. Yilmaz, RSC Adv. 4 (2014) 2219.

[21] G.U. Akkus, S. Memon, M. Sezgin, M. Yilmaz, Clean Soil Air Water 37 (2009) 109.

[22] J. Holub, V. Eigner, L. Vrzal, H. Dvořáková, P. Lhoták, Chem. Commun. 49 (2013) 2798.

[23] S. Elçin, H. Deligöz, Tetrahedron 69 (2013) 6832.

[24] D. Filenko, T. Gotszalk, Z. Kazantseva, O. Rabinovych, I. Koshets, Yu Shirshov, V. Kalchenko, I.W. Rangelow, Sens. Actuators B 111-112 (2005) 264.

[25] S. Okur, M. Kus, F. Ozel, V. Aybek, M. Yilmaz, Talanta 81 (2010) 248.

[26] Ö. Mermer, S. Okur, F. Sümer, C. Özbek, S. Sayin, M. Yilmaz, Acta Phys. Pol. A 121 (2012) 240.

[27] R. Sharma, R. Margani, S.M. Mobin, R. Misra, RSC Adv. 3 (2013) 5785.

[28] C.D. Gutsche, K.C. Nam, J. Am. Chem. Soc. 110 (1988) 6153.

[29] E.M. Collins, M.A. McKervey, E. Madigan, M.B. Moran, M. Owens, G. Ferguson, S.J. Harris, J. Chem. Soc. Perkin Trans. 1 (12) (1991) 3137.

[30] E.A. Alekseeva, V.A. Bacherikov, A.I. Gren, Russ. J. Gen. Chem. 70 (2000) 490. 